\title{
Prototípus alkatrészek elkészítésére kifejlesztett CNC távvezérlése és távfelügyelete
}

\author{
Molnár Zsolt \\ Villamosmérnöki és Mechatronikai Tanszék \\ Debreceni Egyetem, Müszaki Kar \\ Debrecen, Magyarország \\ zsolt.molnar94@gmail.com
}

\author{
Dr. habil Husi Géza \\ Villamosmérnöki és Mechatronikai Tanszék \\ Debreceni Egyetem, Müszaki Kar \\ Debrecen, Magyarország \\ husigeza@eng.unideb.hu
}

\begin{abstract}
Absztrakt-A Debreceni Egyetem Villamosmérnöki és Mechatronikai Tanszékének, Épületmechatronikai Kutatóközpontja biztosított helyet és eszközöket a saját fejlesztésü CNC gép alkatrészeinek a legyártására és összeszerelésére valamint megfelelő infrastruktúrát a távvezérlési rendszer kialakításához és teszteléséhez.

Projektben egy olyan egyedi kivitelezésủ félipari CNC került megépítésre, amelynek alkatrészei könnyen beszerezhetőek, általános marási és vágási feladatokra alkalmas és távvezérelhető valamint felügyelhető.
\end{abstract}

Kulcsszavak-CNC; távfelügyelet; távvezérlés; Raspberry Pi; Linux; Timotei-Robotics

\section{BEVEZETÖ}

Az egyre globalizálódó világunkban az információ áramlás és annak közlése egyre nagyobb hangsúlyt kap, aminek alappillérévé az Internet vált. Ennek rohamos fejlődése alapjaiban változtatta meg, nem csak az emberek életét, hanem a gondolkodásuk metódusára is igen komoly hatást gyakorolt.

Világunkban az Internet által nyújtotta lehetőségek korlátlanok, képesek vagyunk nem csak adatok továbbítására a ezredmásodpercek alatt, hanem komplett távvezérlési és távfelügyeleti rendszerek megtervezésére, kivitelezésére és alkalmazására.

Az Internet elöretörése egyben az ipar rohamos fejlődését is eredményezi, hiszen a tervező programok jelentős hányada Open-Source[1] minősítéssel érhető el, emiatt pedig bárki részt vehet annak fejlesztésében, tesztelésében. A CAD, CAM programok használatával az iparban a tervtől a késztermékig való eljutásig szükséges idő lényegesen lerövidült.

Az ipari világvállatok által a megtervezett és müködtettet gyártósoraik fenntartása komoly feladat. Egy adott ipari szereplő átlagosan több ipari létesítménnyel rendelkezik, egymástól távol, akár több $100 \mathrm{~km}-\mathrm{re}$. Az esetleges meghibásodása vagy átprogramozása az adott gyártósori gépeknek rendkívül időigényes.

Az üzembiztos technológiák alkalmazásával kiforrott, az ipar számára is használható távvezérlés és távfelügyeleti rendeszeket dolgozhatunk ki.
Egy saját távfelügyeleti rendszer tesztelése céljából a Debreceni Egyetem, Villamosmérnöki és Mechatronikai Tanszékének, Épület Mechatronikai Kutatóközpontjának prototípus alkatrészeket készítő laboratóriumában [2] megépítésre került egy félipari $\mathrm{CNC}$, mellyel prototípus alkatrészek elkészítése lehetséges további kutatásokfejlesztések céljából [3]. Az Intelligens Épületben kialakított nagy sebességü internethálózat biztosította a CNC távvezérlésének teszteléséhez szükséges infrastruktúrát [4].

Az alábbi taglalásban kerülnek bemutatásra a félipari $\mathrm{CNC}$ tervezése, kivitelezése és távvezérlése: II. Tervezési szempontok. III. A CNC felépítése. IV. Áramköri elemek. V. Távvezérlés és távfelügyelet. VI. Összegzés. VII. Köszönet nyilvánítás és Referenciák.

\section{TERVEZÉSI SZEMPONTOK}

A CAD, CAM programok alkalmazása általános kisebb projektek terén is, így a hobbi kategóriájú munkákhoz is alkalmazzák. A munkafolyamat lerövidülése abban áll, hogy az elkészített 3D digitális tervekböl közvetlenül lehet a megmunkáló gépek számára értelmezhető kódot, programot generálni.

Ennek a technológiának kisebb munkákhoz, projektekhez való alkalmazásakor legnagyobb hátránya, hogy a CNC maró beszerzése költséges és a legtöbb esetben nem éri meg, mivel az előállított eszköz nem kerül sorozatgyártásra. Ennek a problémának a kiküszöbölésére egy olyan CNC maró megtervezése és megépítése lett kitüzve célul, amely pontossága elegendő a kisebb projektek kivitelezéséhez azonban az alkatrészei könnyen elérhetőek mindenki számára.

A hagyományos marási funkció mellett egy univerzális gép megalkotása is fó szempont, ezért a megmunkáló szerszám egyszerü cseréje is fontos. Így a CNC-t lézervágóként, 3 dimenziós nyomtató[5] és habvágó ként is funkcionálhat.

A tervezés egyik legfontosabb része a 3D modell készítése volt, melyhez az ingyenesen is használható Google által fejlesztett SketchUp[6] program került felhasználásra. A 3D modell tervezésnek egyik előnye, hogy így még virtuálisan megvizsgálhatjuk az elkészült szerkezetet. Ez magába foglalja, 
hogy a kiválasztott alkatrészek az adott összeállításban megfelelően illeszkednek-e, továbbá szimulációk által ellenőrizhető, hogy mozgás közben a különböző alkatrészek között jön-e létre ütközés.Az összeállítása a modellnek a SketchUp program segítségével készült.

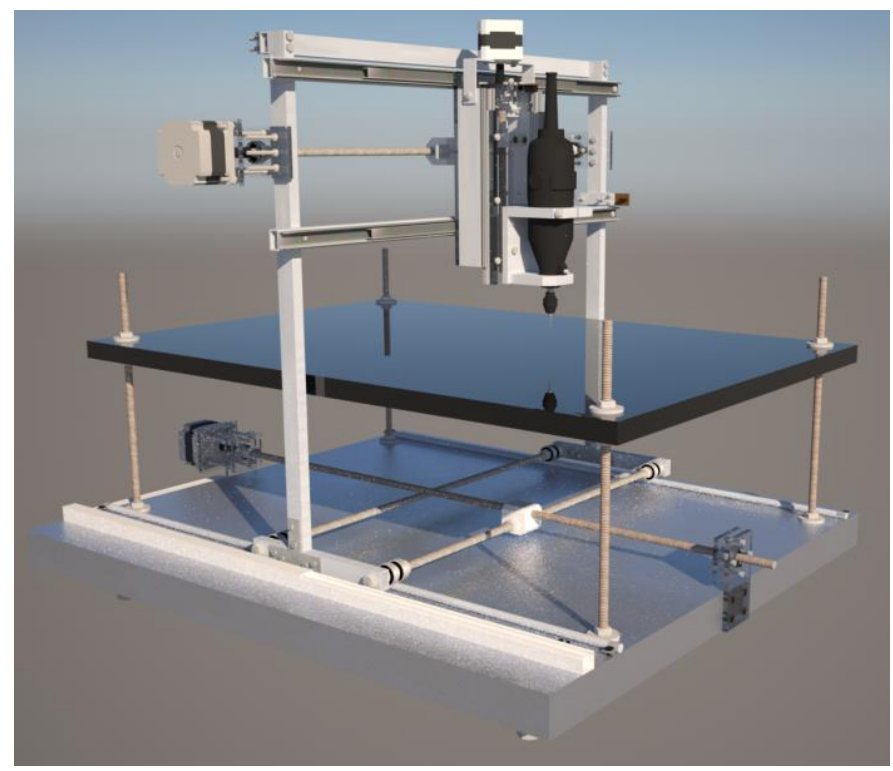

1. ábra: SketchUp programban összeállitott 3D modell Forrás: saját tartalom

Azonban ez nem rendelkezik fizikai motorral, így a szimulációkat aBlender[7], Open-Source minősítésü modellező és szimuláló szoftverrel kerültek elvégzésre. Ennek előnye, hogy rendelkezik ODE (Open Dynamics Engineel)[8], ami szimulációk elvégzésére megfelelőnek bizonyult.A legtöbb modellező és renderelő szoftvert fejlesztők az ODE-t építi be a programjukba fizikai motorként, mivel az ez által létrehozható mozgások száma gyakorlatilag végtelennek tekinthető.

A CNC mozgásának szimulációja során az $\mathrm{X}, \mathrm{Y}$ és $\mathrm{Z}$ tengelyek képezték a vizsgálat tárgyát.

Ezen tesztek lefuttatása után pontosabb képet kaphatunk a megépítendő rendszer müködéséröl és az esetlegesen fellépő hibákról.

\section{A CNC FELÉPÍTÉSE}

A CNC gép szánrendszereinek elemei a Descartes-féle derékszögü koordináta rendszer tengelyeivel párhuzamosan mozognak, így a meghajtását legkevesebb három motor végzi.A meghajtás több féle képen törtéhet: közvetlenül, lineáris motorok[9] által vagy közvetett módom.

A szimulációkat figyelembe véve a választás az orsós hajtásra esett, mivel nagy pontosságot tesz lehetővé, ugyanakkor kisebb forgatónyomatékú motor esetén is biztosítani lehet a marófej számára a szükséges előtolási erőt, megfelelően választva meg az orsó menetemelkedését.

A felsorolt szempontok szerint, az elérhető alkatrészek paraméterei alapján a CNC marónak a következő fö paraméterei lettek meghatározva:
Munkaterület:

- X tengely: $440 \mathrm{~mm}$

- $\quad$ Y tengely: $390 \mathrm{~mm}$

- Z tengely: $100 \mathrm{~mm}$

A CNC munkaasztalának mérete rögzítő pontokat beleértve:

- Hosszúság: $690 \mathrm{~mm}$

- Szélesség: $480 \mathrm{~mm}$

A CNC által elfoglalt tér (motorvezérlö és tápegység nélkül):

- Hosszúság: $820 \mathrm{~mm}$

- Szélesség: $670 \mathrm{~mm}$

- Magasság: $640 \mathrm{~mm}$

Pontosság tekintetében célnak a 0,01mm-es lépésenkénti felbontás lett kitűzve, ami elegendő a legtöbb megmunkálási feladathoz.

A menetorsók meghajtására hibrid léptetőmotorok kerültek beépítésre, ez lehetővé teszi a bipoláris és unipoláris bekötést is. Az elkészült CNC esetén a motorok bipolárisként vannak bekötve, mivel a vezérléséhez szükséges elektronika és logika egyetlen tokba, az A4988 nevü vezérlö integrált áramkörbe (továbbiakban IC) van integrálva.

Ez lényegesen leegyszerüsíti elektronikai téren a gépet, mivel az IC panelra szerelve, Pololu A4988 néven lehet hozzájutni, ami tartalmazza az áramméréshez szükséges ellenállásokat, zavarszürő kondenzátorokat.Továbbá a motor tekercsein átfolyó áramot beállító potenciométert és egyéb, a működéséhez szükséges alkatrészeket. A hordozó áramkör úgy van kialakítva, hogy az IC-n átfolyó áramokból adódó hőt is képes legyen eldisszipálni.

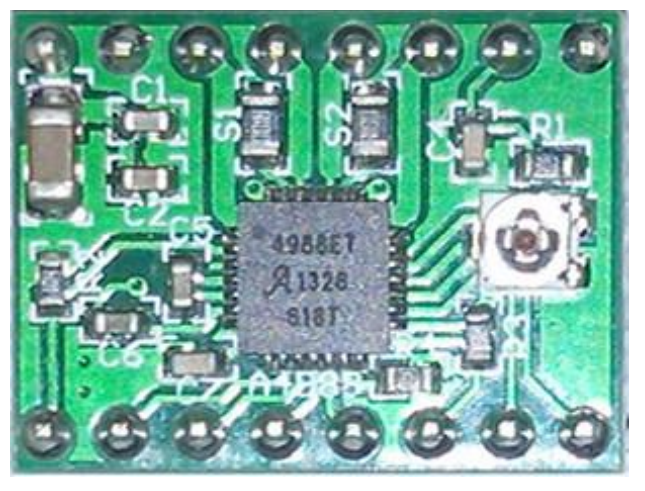

2. ábra: Pololu A4988 motorvezérlö Forrás: saját tartalom

Az áramkör egyik legnagyobb elönye az úgynevezett microstep lépésosztás funkció, amellyel a léptetőmotorok egészlépés szögeit bonthatjuk tovább. A microstep-nél 
megkülönböztetünk 1/2, 1/4, 1/8, 1/16 lépésszögeket az áramkör beállításaitól függően.

A Pololu áramkör a következő paraméterekkel rendelkezik:

- 2 A maximálisan beállítható áram tekercsenként

- 1 A maximális áram hütőborda nélkül

- $\quad 8$ - 35 V között változhat a motorok tápfeszültsége

- $\quad 3,3-5 \mathrm{~V}$ vezérlőlogika tápfeszültség

- Rövidzárlat és túlmelegedés védelemmel[10]

Meghajtó motorok terén az X és Y tengely meghajtásához két NEMA23 és a $Z$ tengely esetén egy NEMA17 rögzítésü motor került felhasználásra. Léptetőmotorokból ezek a legelterjedtebb rögzítési típusok, valamint ilyen rögzítésekkel különböző paraméterekkel rendelkező motorokhoz is könnyen hozzá lehet jutni, így a gép összeállítása során a kitüzött feladathoz lett méretezve a menetorsók hajtását.

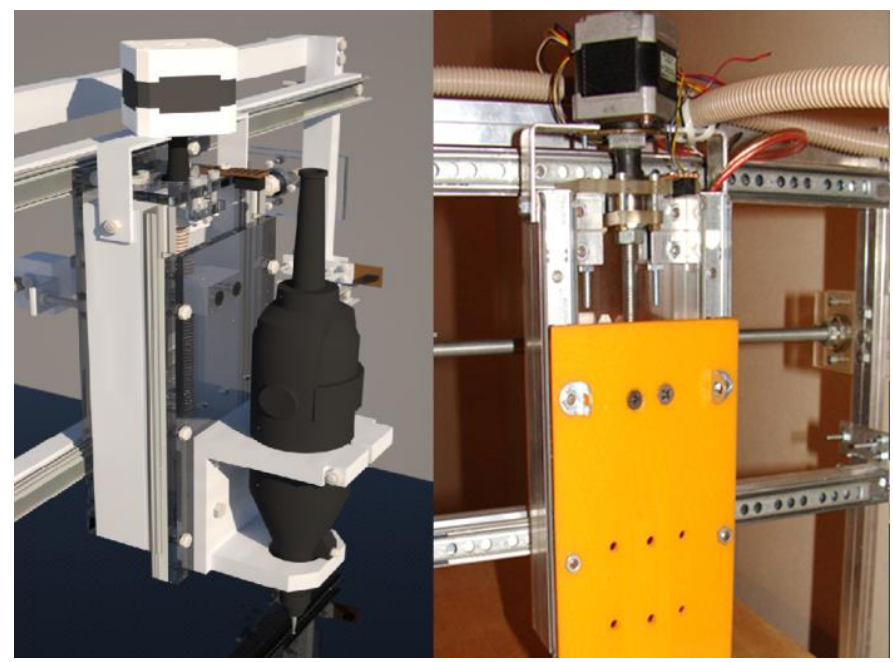

3. ábra: NEMA17 léptetömotor Forrás: saját tartalom

A NEMA17 léptetőmotor paraméterei:

- Típusa: bipoláris hibrid léptetőmotor

- Méretei: 42,3 x 42,3 x $47 \mathrm{~mm}$

- Tengelyátmérő: $5 \mathrm{~mm}$

- Maximális áram fázisonként: 1,2 A

- Feszültség: $5 \mathrm{~V}$

- Nyomaték: 2,6 kgcm

- Tömeg: $225 \mathrm{~g}[11]$

A NEMA23 léptető motor félipari alkalmazásoknál elterjedtebb, hobbi körben elsősorban a fentebb említett NEMA17 motort választják méretei és kedvező ára folytán. Ezen léptetőmotor jellemzően nagy nyomaték kifejtésére képes.

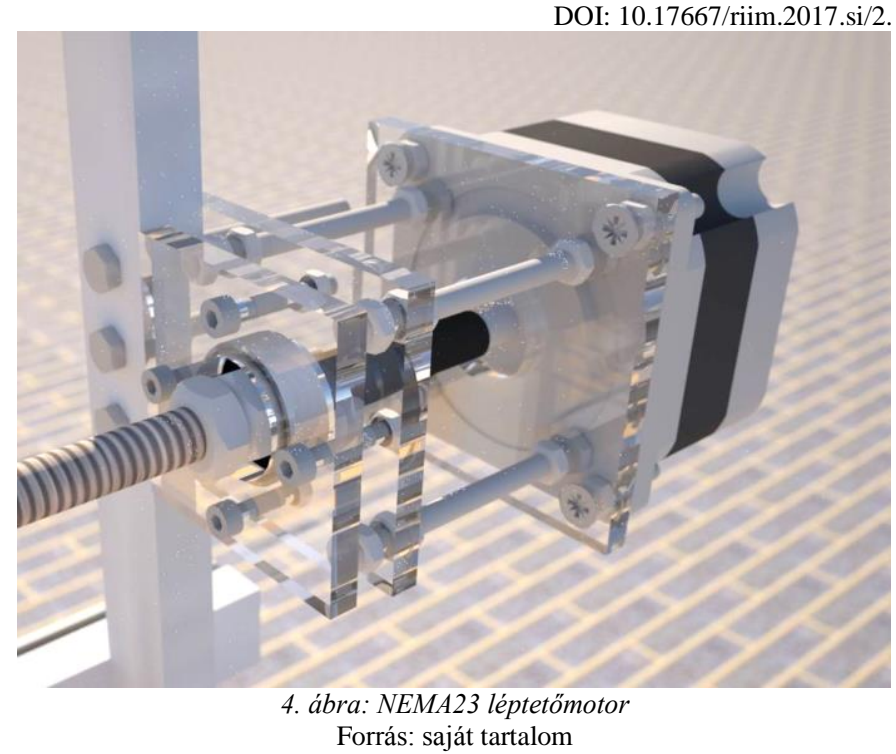

A NEMA23 léptetőmotor paraméterei:

- Típusa: bipoláris hibrid léptetőmotor

- Méretei: 57 x 57 x 53mm

- Tengelyátmérö: $6,35 \mathrm{~mm}$

- Maximális áram fázisonként: $2 \mathrm{~A}$

- Feszültség: 2,8 V

- $\quad$ Nyomaték: $4,2 \mathrm{kgcm}$

- Tömeg: $320 \mathrm{~g}$ [12]

\section{IV. ÁRAMKÖRI ELEMEK}

$\mathrm{Az}$ áramkör tesztelése céljából próbapanelre került megépítésre, ugyanis a felhasznált modulok lábtávolsága a próbapanelek lyukhálójának távolságával kompatibilis, ezzel is lehetővé téve a gyors prototípusépítést és fejlesztési idő lerövidítését.

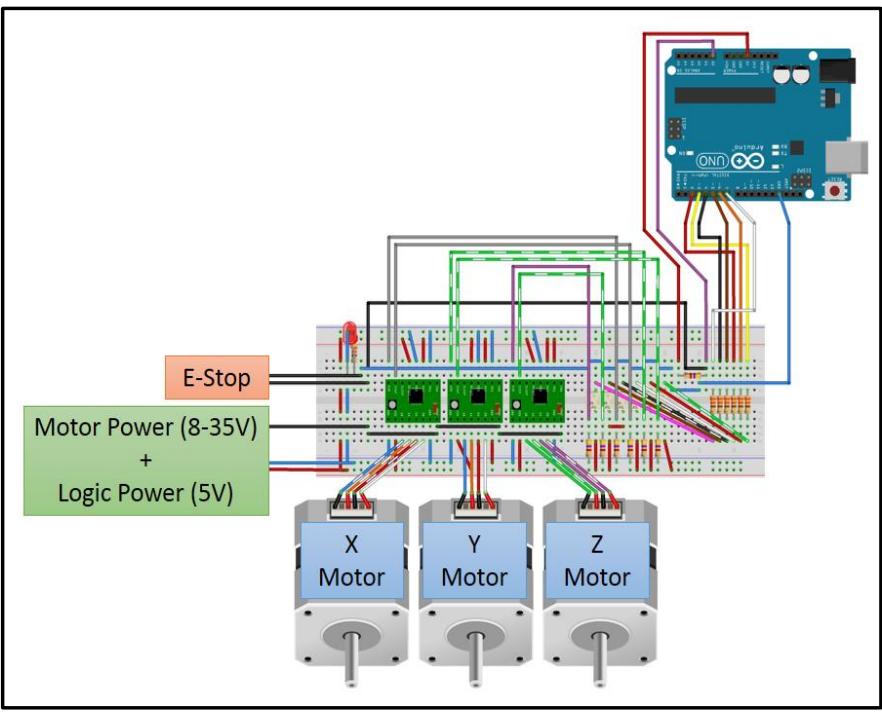

5. ábra: Relé panelek - nyomtatott áramkör

Forrás: saját tartalom 
További előnye, hogy lényeges módosításokat lehet elvégezni az áramkörön különleges szerszámok megléte nélkül. A fó része az áramkörnek az Arduino UNO panel, amelyik a Raspberry $\mathrm{Pi}[13]$ és a Pololu A4988 összekapcsolását végzi valamint a léptetőmotor vezérlő modulok és a galvanikus leválasztást végző 6 optocsatoló.

Az áramkörhöz továbbá bekötésre került egy vészleállító gomb(E-Stop) is, sérülések és károsodások elkerülése végett és más biztonságtechnikai szempontokat figyelembe véve.

\section{TÁVVEZÉRLÉS ÉS TÁVFELÜGYELET}

Az elkészült félipari CNC távvezérlése és távfelügyelete igen komoly kihívást jelentett, mivel a projektben olyan eszközök kerültek felhasználásra, amelyek ilyen területen ebben az összeállításban nem voltak alkalmazva. Koncepciót az alábbi ábra hivatott szemléltetni:

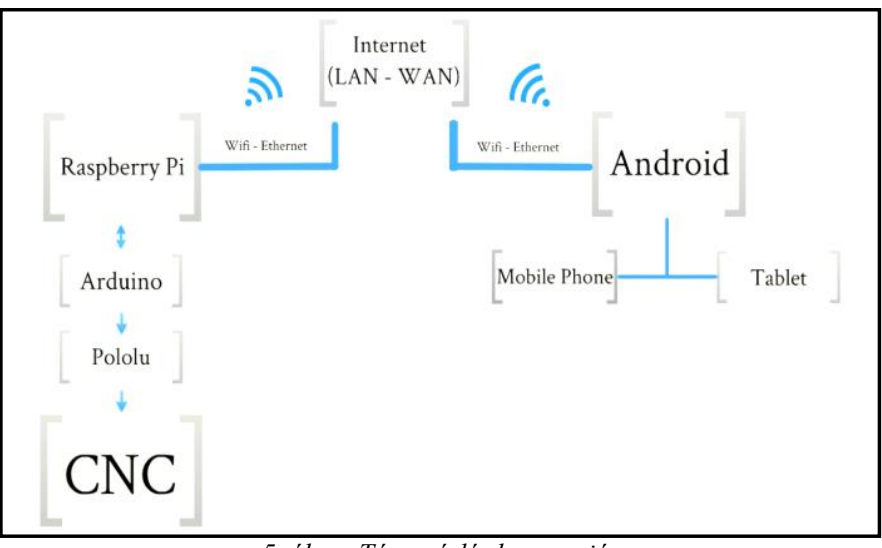

5. ábra: Távvezérlés koncepció

Forrás: saját tartalom

A CNC távvezérlése és távfelügyelete a VNC szerverkliens programkombinációval lett megvalósítva.

A VNC, eredeti nevén Virtual Network Computing [14], egy platformfüggetlen, távoli vezérlést és felügyeletet biztosító program. Jellemzően rendkívül kevés erőforrást igényel, így nem csak asztali számítógépeken és laptopokon, hanem Android alapú tableteken, mobiltelefonokon is futtatható. Az egyik legfontosabb követelmény a program használata szempontjából, hogy az irányított és az irányítandó gépek között helyi hálózati kapcsolatnak kell kiépítve lennie vagy internet eléréssel kell hogy rendelkezzenek az eszközök. A VNC program ebben az esetben az Allview P4 Duo középkategóriásnak tekinthető okostelefonra került feltelepítésre.

A Félipari CNC gépet vezérlő Raspberry Pi számítógépre a Raspbian [15] Linux Distribúció lett feltelepítve LXDE asztali környezettel, amire a VNC és a Grbl[16] G-kód interpreter lett telepítve Terminal-on keresztül. A Grbl egy program, amely a megmunkálás menetét leíró G kódot küldi ki az Arduino számára. A VNC által a vezérléshez felhasznált Androidos eszköz segítségével hozzáférést nyerünk a CNC gépet vezérlő számítógép kezelőfelületéhez és ezzel együtt a Grbl vezérlőprogram felületéhez is, amely segítségével előre meghatározott lépéshosszakon lehet mozgatni a CNC tengelyeit.

A távfelügyelet a program kezelőfelületének, a vezérlő számítógép állapotát, a CNC tengelyeinek állását és G-kód futtatása esetén a tervezett és végrehajtott útvonalról küld visszajelzést a felhasználó számára.

Az ismertetett eszközökböl, az Android rendszert futtató eszköz kivételével, az Épületmechatronikai Kutatóközpont épületében lett elhelyezve, valamint az adott laborban található IP kamerákon keresztül távolról felügyelhetővé vált.

\section{VI. ÖSSZEGZÉS}

A prototípus alkatrészek elkészítésére kifejlesztett CNC távvezérlése és távfelügyelete megvalósításra került.

Pontosság szempontjából az a következtetés került levonásra, hogy míg a személyi számítógépről közvetlenül vezérelve a billentyüzet parancsaira valós időben reagált, addig távvezérlés esetén 0,3 és 0,8másodperc közötti késés jelentkezett. Azonban ez az üzemszerü müködést nem befolyásolta.

Következtetésképp el lehet mondani, hogy a távvezérlés és távfelügyelet az Épületmechatronikai Kutatóközpontban megbízhatóan és biztonságosan müködik.

A mobileszköz biztosítja a távirányítást végző ember számára a mobilitást a készülék felügyelete és programozása mellett.

\section{KÖSZÖNETNYILVÁNÍTÁS}

A fejlesztési és a kutatási forrásokat a Debreceni Egyetem Villamosmérnöki és Mechatronikai Tanszéke bocsátotta rendelkezésünkre.

\section{HIVATKOZÁSOK}

[1] http://en.wikipedia.org/wiki/Open_source 2015.06.14. 12:35

[2] http://eem.eng.unideb.hu/index.php/department/laboratories 2015.04.14. 07:21

[3] G. Husi, P. T. Szemes, E. Dávid, T. I. Erdei, Building Mechatronics Research Centre as energy aware Intelligent Space - Industrial Electronics Society, IECON 2013 - 39th Annual Conference of the IEEE; 01/2013

[4] G. Husi, P. T. Szemes, E. Dávid, T. I. Erdei, G. Pető, Reconfigurable Simulation and Research Toolset for Building Mechatronics. Proceedings of CERiS'13 - Workshop on Cognitive and Eto-Robotics in iSpace. Budapest, 2013. július. ISBN 978- 963-313-086-5

[5] http://www.cnccookbook.com/CCDIYCNCMachineTypes.htm 2015.07.08. 18:54

[6] http://www.sketchup.com/download?sketchup=pro 2015.08.12. 23:33

[7] http://www.blender.org/ 2015.08.26. 19:45

[8] http://www.ode.org/ 2015.08.27. 17:13

[9] http://en.wikipedia.org/wiki/Linear_motor 2015.09.03. 20:22 
[10] http://www.pololu.com/product/1182 2015.09.03. 09:38

[11] http://www.robotshop.com/en/replicator-2-2x-nema-17-hybrid-steppermotor.html

2015.09.03. 20:47

[12] http://www.mpja.com/Stepper-Motor-NEMA-23$28 \mathrm{~V} /$ productinfo/ $18686 \% 20 \mathrm{MS} /$

2015.09.03. 14:49
Recent Innovations in Mechatronics (RIiM) Vol. 4. (2017). No. SI.

DOI: $10.17667 /$ riim.2017.si/2

[13] E. Upton, G. Halfacree, Raspberry Pi User Guide http://www.cs.unca.edu/ bruce/Fall14/360/RPiUsersGuide.pdf 2015.05.18 13:22

[14] http://en.wikipedia.org/wiki/Virtual_Network_Computing 2015.10.03. 01:05

[15] http://www.raspberrypi.org/downloads/ 2015.10.09. 18:55

[16] http://zapmaker.org/raspberry-pi/running-grbl-controller-on-raspberrypi/ 2015.10.15. 21:18 